\title{
IV MIGUEL R. COVIAN SYMPOSIUM NEW CHALLENGES FOR PHYSIOLOGISTS
}

This issue of the Brazilian Journal of Medical and Biological Research contains 19 papers presented at the IV Miguel R. Covian Symposium held May 23-25, 2008 in Ribeirão Preto, SP, Brazil. Leão and von Gersdorff (1) demonstrated the importance of $\mathrm{Ca}^{2+}$ buffering in the developing rat calyx of Held. Garção and Mattioli (2) showed that L-histidine, a histaminergic precursor, impairs memory consolidation in Carassius auratus after cerebellar ablation. Cofiel and Mattioli (3), also using L-histamine, evaluated the role of the histaminergic system in learning and stress and showed its importance in the modulation of these responses in zebrafish. The study by Margatho et al. (4) suggested that central amygdala GABAergic mechanisms are involved in atrial natriuretic peptide and oxytocin secretion in response to blood volume expansion. Nascimento and Branco (5) suggested an interesting synergism between peripheral and spinal heme oxygenase-carbon monoxide pathways that may play an antinociceptive role. Evidence was presented by de Faria et al. (6) that activation of purinergic receptors in the brain may affect water intake in animals submitted to dehydration.

Burnstock (7) reviewed the history of his discovery of purinergic transmission and the role of ATP as a cotransmitter in all nerves of the peripheral and central nervous systems. The possible involvement of purinergic mechanisms in several diseases of the central nervous system was also discussed. In the field of renal physiology, Ma et al. (8) presented a review related to the renal protective effect of the blockade of stress-activated protein kinases p38 and JNK, which may be relevant to therapeutic interventions in human renal disease. Balbi et al. (9) reviewed the interaction of mitogen-activated protein kinases and angiotensin II during renal development. With respect to calcium mechanisms, Petersen (10) presented an important review of the role of $\mathrm{Ca}^{2+}$ signaling in pancreatic acinar cells in physiological and pathophysiological conditions. This review is an excellent example of the translational physiology from basic concepts to a human disease such as pancreatitis. Rodrigues et al. (11) presented an interesting review discussing the role of $\mathrm{Ca}^{2+}$ signaling in the cell nucleus and Navegantes et al. (12) highlighted the mechanisms and effects of $\mathrm{Ca}^{2+}$-dependent protein degradation on oxidative muscles by increasing calpastatin levels and the mechanisms by which endogenous catecholamines induce anabolic muscle effects.

In the cardiovascular field we have three interesting reviews. Durand et al. (13) discussed the technique and the results obtained with electrical stimulation of the aortic depressor nerve in rats and humans and pointed to the possible use of this approach in patients with resistant hypertension. Franchini et al. (14) discussed the signaling mechanisms regulated by focal adhesion kinase and their possible role in the pathophysiology of cardiac hypertrophy and failure. Since the vascular relaxation in response to endogenous nitric oxide or to nitric oxide donors is impaired in renal hypertensive rats, Lunardi et al. (15) suggested that a vascular smooth muscle dysfunction exists in this experimental model.

Ruginsk et al. (16) presented a review of the central effect of glucocorticoids in the control of body fluid homeostasis and the role of endocannabinoids, glutamate neurotransmission and the nuclear factor kappa B pathways. Leonelli et al. (17) discussed the new roles of neurotransmitters in development, plasticity, neurodegeneration and neuroprotection with focus on endocannabinoids and nitric oxide, which are considered to be unconventional neurotransmitters. Garcia-Cairasco (18) discussed epilepsies in the context of neurobiological models of high complexity systems displaying maladaptive plasticity. Different concepts involving multidisciplinary approaches to the study of epilepsy were also explored. Cardoso et al. (19) presented a review of a model for the circadian timing system of mammals to reproduce the endogenous generation and synchronization to the light-dark cycle, which exhibit responses consistent with physiological patterns.

On behalf of the Organizing Committee (Benedito $\mathrm{H}$. Machado, Luiz Carlos C. Navegantes and Wamberto A. Varanda), I wish to thank the participants and especially the authors and reviewers who contributed to this issue of the Brazilian Journal of Medical and Biological Research. The quality and ideas presented in the papers published in this issue dedicated to the Symposium demonstrate that the mission of the IV Miguel R. Covian Symposium to provide a platform for the discussion of new concepts and new challenges for physiologists was accomplished.

Benedito H. Machado

Guest Editor 


\section{References}

1. Leão RM, von Gersdorff H. Synaptic vesicle pool size, release probability and synaptic depression are sensitive to $\mathrm{Ca}^{2+}$ buffering capacity in the developing rat calyx of Held. Braz J Med Biol Res 2009; 42: 94-104.

2. Garção DC, Mattioli R. L-histidine reduces inhibitory avoidance in Carassius auratus submitted to cerebellar ablation. Braz J Med Biol Res 2009; 42: 135-140.

3. Cofiel LPV, Mattioli R. L-histidine enhances learning in stressed zebrafish. Braz J Med Biol Res 2009; 42: 128-134.

4. Margatho LO, Elias LLK, Antunes-Rodrigues J. GABA in the central amygdaloid nucleus modulates the electrolyte excretion and hormonal responses to blood volume expansion in rats. Braz J Med Biol Res 2009; 42: 114-121.

5. Nascimento CGO, Branco LGS. Antinociception synergy between the peripheral and spinal sites of the heme oxygenase-carbon monoxide pathway. Braz J Med Biol Res 2009; 42: 141-147.

6. de Faria DRG, Santana JS, Menani JV, de Paula PM. Antidipsogenic effects of central adenosine-5'-triphosphate. Braz J Med Biol Res 2009; 42: 105-113.

7. Burnstock G. Purinergic signalling: past, present and future. Braz J Med Biol Res 2009; 42: 3-8.

8. Ma FY, Liu J, Nikolic-Paterson DJ. The role of stressactivated protein kinase signaling in renal pathophysiology. Braz J Med Biol Res 2009; 42: 29-37.

9. Balbi APC, Francescato HDC, Marin ECS, Costa RS, Coimbra TM. Roles of mitogen-activated protein kinases and angiotensin II in renal development. Braz J Med Biol Res 2009; 42: 38-43.

10. Petersen $\mathrm{OH} . \mathrm{Ca}^{2+}$ signaling in pancreatic acinar cells: physiology and pathophysiology. Braz J Med Biol Res 2009;
42: 9-16.

11. Rodrigues MA, Gomes DA, Nathanson MH, Leite MF. Nuclear calcium signaling: a cell within a cell. Braz J Med Biol Res 2009; 42: 17-20.

12. Navegantes LCC, Baviera AM, Kettelhut IC. The inhibitory role of sympathetic nervous system in the $\mathrm{Ca}^{2+}$-dependent proteolysis of skeletal muscle. Braz J Med Biol Res 2009; 42: 21-28.

13. Durand MT, Fazan R Jr, Salgado MCO, Salgado HC. Acute and chronic electrical activation of baroreceptor afferents in awake and anesthetized subjects. Braz J Med Biol Res 2009; 42: 53-60.

14. Franchini KG, Clemente CFMZ, Marin TM. Focal adhesion kinase signaling in cardiac hypertrophy and failure. Braz $J$ Med Biol Res 2009; 42: 44-52.

15. Lunardi CN, da Silva RS, Bendhack LM. New nitric oxide donors based on ruthenium complexes. Braz J Med Biol Res 2009; 42: 87-93.

16. Ruginsk SG, Lopes da Silva A, Ventura RR, Elias LLK, Antunes-Rodrigues $\mathrm{J}$. Central actions of glucocorticoids in the control of body fluid homeostasis: Review. Braz J Med Biol Res 2009; 42: 61-67.

17. Leonelli M, Torrão AS, Britto LRG. Unconventional neurotransmitters, neurodegeneration and neuroprotection. Braz J Med Biol Res 2009; 42: 68-75.

18. Garcia-Cairasco N. Learning about brain physiology and complexity from the study of the epilepsies. Braz J Med Biol Res 2009; 42: 76-86.

19. Cardoso FRG, Cruz FA de O, Silva D, Cortez CM. A simple model for circadian timing by mammals. Braz $\mathrm{J}$ Med Biol Res 2009; 42: 122-127. 